\title{
Tatalaksana Jalan Napas pada Kasus Mukopolisakaridosis tipe II: Kasus Serial
}

\author{
Anas Alatas ${ }^{1}$, Budi Pratama ${ }^{1}$
}

1. Departemen Anestesiologi dan Terapi Intensif, Fakultas Kedokteran Universitas Indonesia, RSUPN Dr. Cipto Mangunkusumo, Jakarta, Indonesia

\begin{abstract}
ABSTRAK
Mukopolisakaridosis tipe II atau dikenal dengan nama sindrom Hunter adalah kumpulan kelainan metabolik yang diturunkan secara resesif, bersifat progresif dan disebabkan oleh defisiensi enzim lisosom yang diperlukan untuk mendegradasi glikosaminoglikan. Keadaan tersebut menyebabkan kelainan anatomi dan keterlibatan sistemik yang merupakan tantangan bagi seorang ahli anestesi. Laporan kasus ini merupakan kasus serial terhadap tiga orang pasien yang akan menjalani prosedur operasi dan penunjang diagnostik dengan tatalaksana jalan napas yang berbeda pula.
\end{abstract}

Kata Kunci : mukopolisakaridosis, tatalaksana jalan napas, anestesi 


\title{
Airway management in Mucopolysaccharidoses type II: A Case Series
}

\author{
Anas Alatas ${ }^{1}$, Budi Pratama ${ }^{1}$
}

1. Departement of Anesthesiology and IntensifCare, Faculty of Medicine, Universitas Indonesia, Dr. Cipto Mangunkusumo National General Hospital, Jakarta, Indonesia

*corresponding author

\begin{abstract}
Mucopolysaccharidoses type II, widely known as Hunter syndrome, is a recessive disease with a group of progressive metabolic disorder. This condition is caused by a deficiency of lysosomal enzymes required for the degradation of glycosaminoglycans. Anatomical and systemic changes experienced by these patients are a challenge for the anesthesiologist. We report a serial case of three patients who underwent operation as well as diagnostic procedures with different approaches for the airway management.
\end{abstract}

Keywords: Mucopolysaccharidoses, airway management, anesthesia 


\section{PENDAHULUAN}

Mukopolisakaridosis tipe II merupakan penyakit langka yang ditandai dengan adanya gangguan metabolisme mukopolisakarida yang diakibatkan defisiensi enzim lisosom. Karena tidak dapat dimetabolisme sempurna, tumpukan glikosaminoglikan akan mengubah struktur jaringan dan organ sehingga pasien yang menderita sindrom Hunter membutuhkan operasi berulang. Berdasarkan informasi dari Kementerian Kesehatan Republik Indonesia, terdapat 30 pasien Mukopolisakaridosis tipe I, II, III, IV A, VI, VIII yang didiagnosis dan ditangani di RSCM. $^{1}$ Ini merupakan tantangan bagi seorang ahlianestesi dalam menentukan teknik anestesi yang tepat. Pemahaman patofisiologi dan pendekatan multidisiplin diharapkan dapat meningkatkan harapan hidup bagi pasien penderita sindrom Hunter. Dalam kasus serial ini, kami menuliskan pengalaman tatalaksana jalan napas pada pasien mukopolisakaridosis tipe II yang menjalani prosedur operasi dan/atau prosedur diagnostik.

\section{LAPORAN KASUS}

\section{Kasus 1}

\section{Praoperatif}

Pasien anak laki - laki, berusia 4 tahun, mengeluhkan jari-jari tangan dan kaki tampak kaku, terutama daerah persendian. Pasien dirujuk ke RSCM dan didiagnosis dengan mukopolisakaridosis tipe II setelah melalui serangkaian pemeriksaan. Pasien sudah mendapat terapi enzim Elapse yang ke-17 di RSCM untuk tatalaksananya. Ibu pasien sering mengeluhkan pasien mengorok saat tidur dan mengalami keterlambatan bicara. Pasien kemudian didiagnosis juga dengan hipertrofi tonsil adenoid dan otitis media efusi bilateral. Setelah dirujuk ke dokter THT untuk tatalaksana lanjutan, pada pasien direncanakan untuk pembedahan tonsiloadenoidektomi, pemeriksaan Brain Evoked Response Audiometry (BERA) dan pemasangan pipa grommet menggunakan anestesi umum.

Pasien belum pernah menjalani prosedur operasi sebelumnya, namun sudah pernah dua kali disedasi tanpa komplikasi untuk pemeriksaan penunjang berupa CT Scan dan MRI. Dari pemeriksaan fisik sebelum operasi, pasien tampak aktif dengan kontak adekuat. Tanda vital relatif dalam batas normal dengan tekanan darah 105/61 mmHg, denyut nadi 98x/menit, laju pernapasan $22 x /$ menit, saturasi oksigen $100 \%$ dalam udara ruang, dan suhu tubuh $360 \mathrm{C}$. Pasien dapat membuka mulut 3 jari dengan nilai mallampati II, namun ekstensi leher tidak dapat maksimal karena kaku leher (Gambar 1).
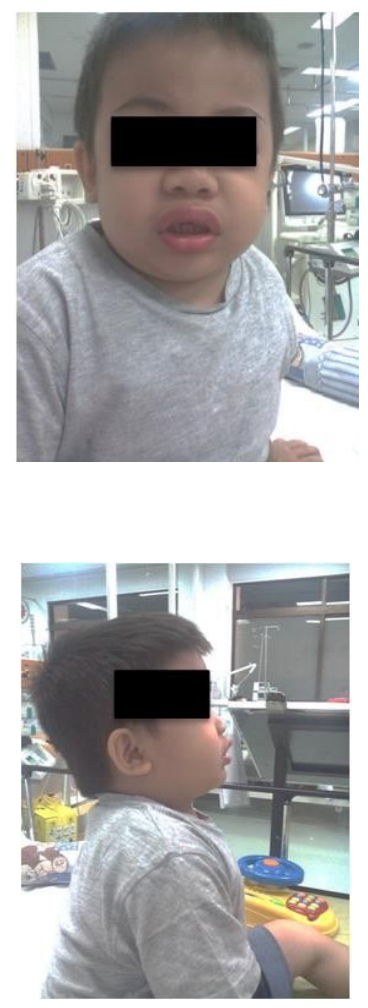

Gambar 1. Foto pasien 1 saat preoperatif

Pemeriksaan intraoral didapatkan ukuran lidah relatif besar terhadap rongga mulut, arkus faring simetris, dengan uvula ditengah, dan tampak tonsil berukuran T2a - T2a. Dari pemeriksaan persendian dan ekstremitas secara keseluruhan juga dapat dinilai adanya keterbatasan gerak pada persendian. Pemeriksaan fisik paru, jantung, dan abdomen dalam batas normal. Pasien dapat diajak berkomunikasi, dapat menjawab dengan isyarat maupun mengikuti instruksi dari ibu pasien. Pemeriksaan tes enzim mukopolisakaridosis sebelum operasi menunjukkan adanya penurunan aktivitas dari enzim Iduronate-2-sulphatase yang sesuai dengan gambaran mukopolisakridosis tipe II atau sindrom Hunter. Pemeriksaan penunjang laboratorium dan rontgen toraks 
sebelum operasi dalam batas normal. Radiologi servikal menunjukkan adanya penyempitan kanalis spinalis, namun tidak tampak tanda ketidakstabilan maupun subluksasi sendi atlantoaxial. Pemeriksaan bone survey menunjukkan adanya frontal bossing disertai pelebaran diameter antero-posterior kalvaria, suspek kraniosinostosis sutura sagitalis dan lambdoidea, vertebra servikal yang berbentuk seperti peluru, dan bentuk basis metacarpal II-V manus bilateral yang meruncing. Pada pemeriksaan tersebut struktur falang proksimal digiti $\mathrm{V}$ pedis bilateral belum terlihat. Pemeriksaan ekokardiografi relatif dalam batas normal.

Dari hasil evaluasi preoperatif pasien dinilai sebagai ASA 2 dengan mukopolisakaridosis tipe II sindrom Hunter, kemungkinan sulit intubasi karena ekstensi leher dan kepala yang terbatas, dan adanya makroglosia. Pasien direncanakan pembiusan umum dengan rencana intubasi dalam posisi leher stabil inline dengan videolaringoskop. Untuk persiapan intubasi disiapkan bougie ukuran anak dan neonatus, C-MAC, glidescope, dan juga fiberoptik.

\section{Perioperatif}

Saat masuk ke ruang operasi, pasien sudah terpasang akses $24 \mathrm{G}$, diberikan premedikasi midazolam 0,5 mg dan ketamin $10 \mathrm{mg}$ intravena di ruang penerimaan pasien. Pasien kemudian dipasangkan monitor, didapatkan hasil pemeriksaan preinduksi, yaitu frekuensi denyut nadi $120 x /$ menit, laju napas $26 x /$ menit, tekanan darah $120 / 90 \mathrm{mmHg}$, dan saturasi $100 \%$. Pasien diberikan fentanyl $2 \mathrm{mcg} / \mathrm{kgBB}$ dan induksi dengan propofol $2 \mathrm{mg} / \mathrm{kgbb}$ intravena.

Pada pasien dilakukan napas spontan dan teknik jaw thrust dengan mempertahankan posisi stabil leher lurus (inline). Setelah pasien dipastikan dapat diventilasi dengan mudah, diberikan pelumpuh otot atrakurium $0,6 \mathrm{mg} / \mathrm{kgbb}$ intravena. Setelah kurang lebih 3 menit, dilakukan laringoskopi dengan tetap mempertahankan posisi stabil leher lurus (inline).

Percobaan intubasi pertama dilakukan menggunakan C-MAC dan blade ukuran anak, namun visualisasi epiglotis sulit dilakukan. Visualisasi terbaik yang didapat hanyalah sedikit ujung epiglotis dan pita suara tidak terlihat. Kemudian dilakukan percobaan dengan memasukkan bougie ke dalam trakea melalui visualisasi yang terbatas tersebut sebanyak tiga kali percobaan namun tidak berhasil. Usaha intubasi kedua menggunakan fiberoptik per oral dengan posisi inline dipertahankan. Visualisasi menggunakan fiberoptik lebih sulit dilakukan karena lidah pasien yang besar dan juga struktur jalan napas pasien yang terkesan banyak lipatan mukosa. Usaha intubasi menggunakan fiberoptik ini sempat dicoba selama kurang lebih 10 menit dengan beberapa kali diselingi ventilasi untuk mempertahankan saturasi oksigen pasien.

Pasien juga sempat diintubasi dengan glidescope namun tidak memberikan hasil yang lebih baik dibandingkan C-MAC karena terdapat kerusakan pada ujung blade glidescope. Usaha terakhir dilakukan intubasi dengan menggunakan kombinasi LMA, bougie neonatus, dan fiberoptik. Kami menggunakan LMA unique nomer 2 yang sudah dipotong bagian pembatas karetnya (aperture bars) agar bagian ujung akhir pipa LMA (laryngeal inlet) bisa dilewati fiberoptik dan bougie. Kami juga memastikan fiberoptik dan bougie dapat masuk ke dalam lumen pipa LMA bersamaan, seperti yang dapat dilihat pada Gambar 2.

Sebelum intubasi dilakukan lagi, dilakukan ins ersi dan ventilasi dengan LMA terlebih dahulu. Setelah dipastikan LMA dapat berfungsi dengan baik, fiberoptik dimasukkan melalui LMA dan didapatkan visualisasi rima glotis. Tampak aritenoid di bagian depan dan di bawah rima glotis. Epiglotis tidak terlihat melalui fiberoptik karena berada dibagian atas LMA. Mukosa sekitar rima glotis tampak edema dan juga menonjol. Bougie kemudian dimasukkan melalui LMA ke dalam rima glottis. Setelah bougie berhasil masuk, fiberoptik dan LMA dikeluarkan, kemudian ETT no 4 non kinking dimasukkan melalui bougie. ETT difiksasi dengan batas bibir $16 \mathrm{~cm}$ dan dihubungkan ke ventilator, kemudian pasien dipersiapkan untuk operasi.

Pasien dibangunkan hingga sadar penuh sebelum diekstubasi. Setelah diekstubasi, pasien diberikan suplementasi oksigen dengan menggunakan sungkup yang pelan-pelan dititrasi turun hingga udara ruang. Pasien masih cenderung mengorok dan mengantuk namun saturasi oksigen berkisar antara 97-98\% dengan 


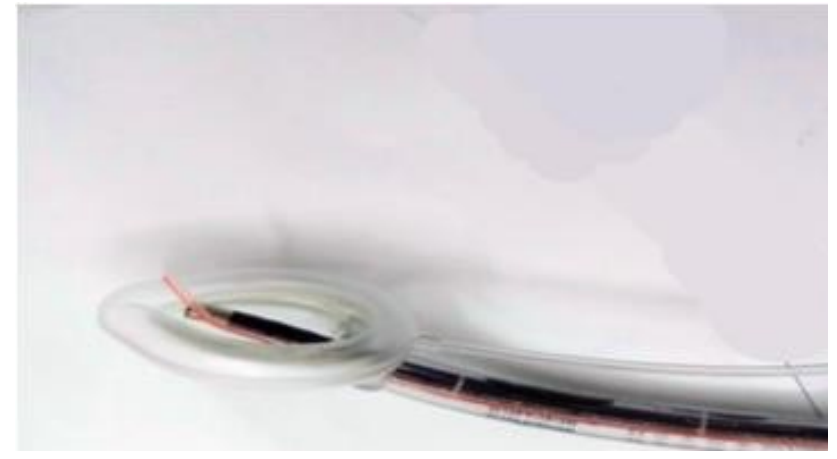

Gambar 2. Kombinasi LMA, fiberoptik, dan bougie ukuran neonatus yang digunakan

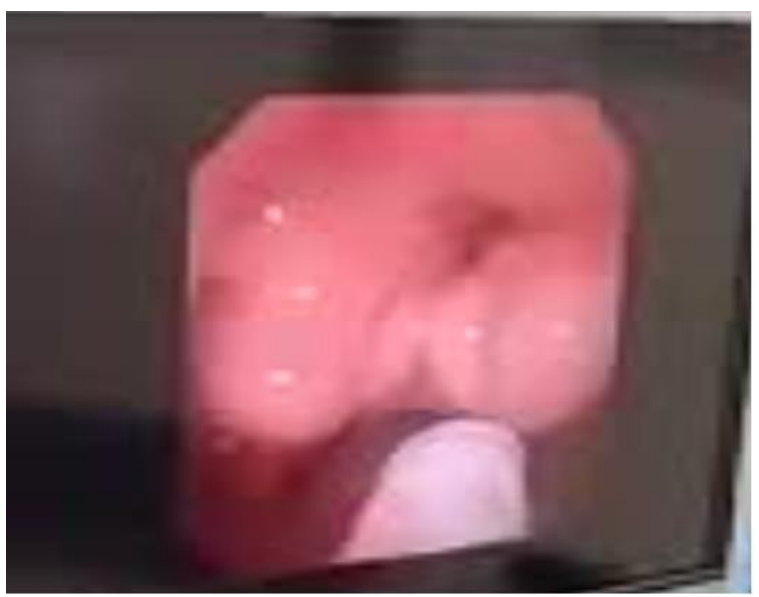

Gambar 3. Gambaran bougie dan jalan napas pasien dengan fiberoptik yang melalui pipa LMA

udara ruang dan pasien dapat dibangunkan dengan mudah. Pasien kemudian ditranspor ke PICU untuk observasi post operatif.

\section{Pascaoperatif}

Evaluasi setelah 24 jam pascapembiusan, kondisi pasien di PICU pasien relatif stabil dengan denyut nadi 80-90x/menit, tekanan darah 105-120/60$90 \mathrm{mmHg}$ dan saturasi oksigen $95-100 \%$ dalam udara ruang. Pasien kemudian dipindahkan ke ruang rawat.

\section{Kasus 2}

\section{Preoperatif}

Anak laki-laki, berusia 5 tahun, berat badan 16,6 kg dikeluhkan oleh orang tuanya karena sering batuk berdahak, kadang-kadang mengorok saat tidur, cenderung membuka mulut saat bernapas, disertai keterlambatan bicara dan gangguan pendengaran. Sejak usia 1 tahun pasien didiagnosis sindrom Hunter dan sudah menjalani terapi sulih enzim dengan idursulfase sejak usia 1,5 tahun. Pasien dikonsulkan ke dokter THT dengan keluhan tersebut dan diputuskan untuk tonsiloadenoidektomi yang ketiga dan BERA (Brainstem evoked response audiometry). Pasien sudah dua kali menjalani operasi tonsil (pertama intubasi dengan laringoskopi direk kombinasi dengan bougie, kedua intubasi dengan videolaringoskopi kombinasi dengan bougie) dan 1 kali sedasi untuk CT scan. Pemeriksaan tanda vital dalam batas normal. Pada pemeriksaan fisik, tampak perawakan pendek dan facies coarse. Tanda vital dalam batas normal. Tidak terdengar suara napas tambahan. Pada pemeriksaan jalan napas, didapatkan pembukaan mulut kesan lebar lebih dari 3 jari, tampak lidah besar, malampati III, dan leher pendek dengan keterbatasan gerak sendi leher. Pemeriksaan intraoral didapatkan kavum nasi yang lapang tanpa sekret, dengan turbinat inferior yang eutrofi. Arkus faring simetris dengan hipertrofi tonsil (T2a - T2a), tidak hiperemis. Tampak hipertrofi adenoid dari pemeriksaan rinofaringolaringoskop. Kartilago aritenoid dan lipatan ariepiglotik tampak lobulated yang berpotensi menyempitkan jalan napas. Pergerakan plica vocalis dan vestibularis simetris, rima glottis terbuka, tidak tampak sekret. Tidak ditemukan kelainan pada pemeriksaan fisik lainnya maupun pemeriksaan penunjang kecuali CT scan nasofaring menunjukkan hipertrofi adenoid yang menyempitkan rongga nasofaring dan penebalan dinding orofaring sisi kanan akibat hipertrofi tonsil palatina.

Pasien dinilai sebagai ASA 2, dengan penyulit sindrom Hunter dalam terapi sulih enzim, disertai keterlambatan bicara, gangguan pendengaran. Pasien juga dinilai dengan kemungkinan sulit jalan napas akibat hipertrofi tonsiladenoid, leher pendek, dan keterbatasan gerak sendi leher.

Pembiusan direncanakan menggunakan pembiusan umum dengan intubasi dalam posisi leher stabil tetap lurus (inline) dengan bantuan video laringoskopi. Untuk persiapan intubasi disiapkan bougie ukuran anak, C-MAC dan juga fiberoptik. 

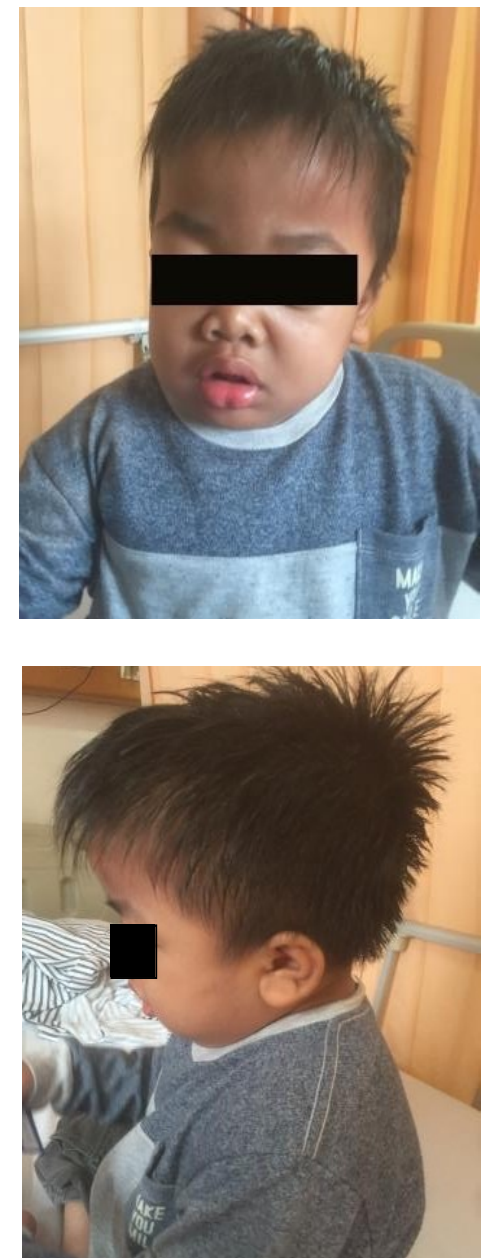

Gambar 4. Facies coarse dan leher pendek pasien 2 yang khas pada sindrom Hunter

\section{Perioperatif}

Pasien tiba di kamar operasi dengan akses vena telah terpasang. Pasien tidak diberikan premedikasi dikarenakan ada kemungkinan sulit jalan napas. Dari pemeriksaan preinduksi didapatkan denyut nadi 104x/menit, laju napas $24 x /$ menit, tekanan darah 108/71 $\mathrm{mmHg}$, dengan saturasi $100 \%$. Induksi intravena menggunakan fentanyl $2 \mathrm{mcg} / \mathrm{kg}$ dan propofol $2,5 \mathrm{mg} / \mathrm{kg}$. Pasien diberikan ganjalan tipis di bawah bahu dan kepala agar posisi kepala tidak ekstensi, menyerupai posisi tidur pasien seharihari. Ventilasi dapat dikuasai tanpa ekstensi kepala. Sevoflurane 2 vol\% diberikan untuk mempertahankan kedalaman anestesi sambil mempertahankan napas spontan.

Intubasi dilakukan menggunakan video laringoskop sambil menjaga agar kepala tidak ekstensi. Dari video laringoskop tampak gambaran Cormack Lehane I, tetapi bila dilihat secara direk visualisasi glottis hanya mencapai Cormack Lehane III (Gambar 5). Visualisasi secara direk lebih sulit karena keterbatasan gerak sendi leher. ETT dimasukkan dengan bantuan bougie. Pasien kemudian dipasang ETT no 5.0 tanpa cuff dengan kedalaman $16 \mathrm{~cm}$ dan dipasang pack. Setelah ETT terpasang, diberikan atracurium $0,25 \mathrm{mg} / \mathrm{kg}$. Rumatan anestesi dipertahankan menggunakan sevoflurane $2-2,5$ vol\%, fentanyl $1 \mathrm{mcg} / \mathrm{kg}$ intermiten, dan atracurium $0,25 \mathrm{mg} /$ kg intermiten.

Di akhir operasi, diberikan reverse pelumpuh otot sepenuhnya, kemudian pasien diekstubasi dalam keadaan sadar penuh. Pasien dikirim ke PICU untuk pemantauan pasca operasi.

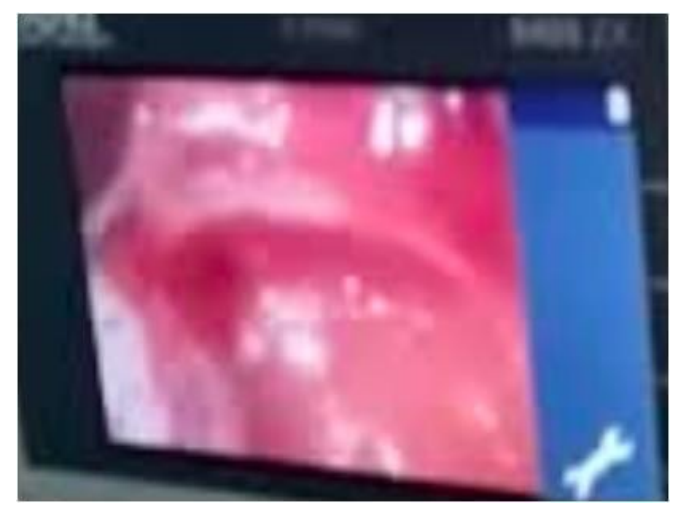

Gambar 5. Visualisasi saat dilakukan intubasi dengan menggunakan video laringoskopi.

\section{Post operatif}

Dilakukan evaluasi 24 jam pasca pembiusan di PICU. Pasien relatif stabil dengan denyut nadi 80-90x/menit, tekanan darah 100-120/60-90 $\mathrm{mmHg}$ dan saturasi oksigen $98-100 \%$ dalam udara ruang. Pada hari berikutnya, pasien dapat dipindahkan ke ruang rawat biasa tanpa ada penyulit. Pasien pulang ke rumah pada perawatan hari ketiga pasca operasi.

\section{Kasus 3 \\ Preoperatif}

Anak laki-laki, berusia 1 tahun, berat badan 13,7 kg dirujuk ke poli THT dengan keluhan ISPA berulang dan mengorok saat tidur dan disertai keterlambatan bicara. Sejak usia 6 bulan pasien didiagnosis sindrom Hunter serta sudah menjalani terapi sulih enzim dengan idursulfase sejak usia 
1 tahun. Pasien memiliki hipertrofi tonsil dan adenoid dan direncanakan untuk tindakan tonsiloadenoidektomi. Pasien belum pernah menjalani operasi dan sedasi. Sehari-hari pasien dikatakan aktif. Tampak perawakan pendek dan facies coarse. Pemeriksaan tanda vital dalam batas normal. Pada pemeriksaan jalan napas didapatkan pembukaan mulut kesan lebar lebih dari 3 jari, malampati II-III, dan leher pendek dengan keterbatasan gerak sendi dikarenakan kaku leher, lidah ukuran besar dengan tonsil T2a-T2a. Hasil laboratorium dan rontgen toraks dalam batas normal. Pemeriksaan ekokardiografi didapatkan ASD secundum $7 \mathrm{~mm} L$ to $R$ shunt. Pasien dinilai sebagai ASA 3, dengan penyulit PJB asianotik, klinis tidak ada riwayat kebiruan tanpa terapi, sindrom Hunter dalam terapi sulih enzim, disertai keterlambatan bicara. Pasien juga dinilai dengan kemungkinan sulit jalan napas akibat hipertrofi tonsiladenoid, leher pendek, dan keterbatasan gerak sendi leher. Pasien dipersiapkan untuk puasa makan padat dan susu mulai dari enam jam sebelum operasi, puasa air mineral mulai dari dua jam sebelum operasi, dan direncanakan pembiusan umum dengan intubasi dalam posisi leher stabil tetap lurus (inline) menggunakan bantuan video laringoskopi. Untuk persiapan intubasi disiapkan bougie ukuran anak dan neonatus, C-MAC, dan juga fiberoptik.

\section{Perioperatif}

Pasien tiba di kamar operasi dengan akses vena perifer telah terpasang. Pasien diberikan premedikasi ketamin $5 \mathrm{mg}$ dan midazolam 0,5 mg, pasien tampak kooperatif dan tenang. Dipasang monitoring sesuai standar ASA, di dapatkan pemeriksaan preinduksi didapatkan frekuensi nadi $108 x /$ menit, laju napas $24 x$ /menit, tekanan darah 110/62 $\mathrm{mmHg}$, dengan saturasi $100 \%$. Dilakukan induksi intravena menggunakan fentanyl $2 \mathrm{mcg} / \mathrm{kg}$ dan propofol $2,5 \mathrm{mg} / \mathrm{kg}$. Diberikan juga ganjalan tipis di bawah bahu dan kepala agar posisi kepala tidak ekstensi. Ventilasi dikuasai tanpa harus ekstensi. Sevoflurane 2-2,5 vol\% diberikan untuk mempertahankan kedalaman anestesi, sambil mempertahankan napas spontan. Intubasi awalnya dilakukan menggunakan video laringoskop sambil menjaga agar kepala tidak ekstensi, namun pada video laringoskop yang disiapkan hanya tersedia blade miller No. 1 (blade lain rusak) yang mana tidak sampai ke epiglotis dan tampak epiglotis letak tinggi (gambar 7). Diputuskan untuk intubasi direk laringoskopi dengan blade Macintosh No. 3, tampak gambaran Cormack Lehane IV. Visualisasi secara direk lebih sulit karena keterbatasan gerak sendi leher. Kemudian dicoba dengan memasukkan bougie ke dalam trakea melalui visualisasi yang terbatas tersebut, namun baru berhasil pada percobaan keempat. Pada pasien kemudian dipasang ETT no 4.0 non kinking dengan kedalaman $14 \mathrm{~cm}$ dan dipasang pack. Setelah ETT terpasang, diberikan atracurium $0,25 \mathrm{mg} / \mathrm{kg}$. Rumatan anestesi dipertahankan menggunakan sevoflurane $2-2,5$ vol\%, fentanyl $1 \mathrm{mcg} / \mathrm{kg}$ intermiten, dan atracurium $0,25 \mathrm{mg} / \mathrm{kg}$ intermiten. Pada akhir operasi, pelumpuh otot di-reverse sepenuhnya. Pasien kemudian diekstubasi dalam keadaan sadar penuh. Pasien kemudian dikirim ke PICU untuk pemantauan pascaoperasi. Teknik multimodal analgesia merupakan Intubasi awalnya dilakukan menggunakan video laringoskop sambil menjaga agar kepala tidak ekstensi, namun pada video laringoskop yang disiapkan hanya tersedia blade miller No. 1 (blade lain rusak) yang mana tidak sampai ke epiglotis dan tampak epiglotis letak tinggi (gambar 7). Diputuskan untuk intubasi direk laringoskopi dengan blade Macintosh No. 3, tampak gambaran Cormack Lehane IV. Visualisasi secara direk lebih sulit karena keterbatasan gerak sendi leher. Kemudian dicoba dengan memasukkan bougie ke dalam trakea melalui visualisasi yang terbatas tersebut, namun baru berhasil pada percobaan keempat. Pada pasien kemudian dipasang ETT no 4.0 non kinking dengan kedalaman $14 \mathrm{~cm}$ dan dipasang pack. Setelah ETT terpasang, diberikan atracurium $0,25 \mathrm{mg} / \mathrm{kg}$. Rumatan anestesi dipertahankan menggunakan sevoflurane $2-2,5$ vol\%, fentanyl $1 \mathrm{mcg} / \mathrm{kg}$ intermiten, dan atracurium $0,25 \mathrm{mg} / \mathrm{kg}$ intermiten. Pada akhir operasi, pelumpuh otot di-reverse sepenuhnya. Pasien kemudian diekstubasi dalam keadaan sadar penuh. Pasien kemudian dikirim ke PICU untuk pemantauan pascaoperasi.

\section{Post operatif}

Pada evaluasi yang dilakukan setelah 24 jam 

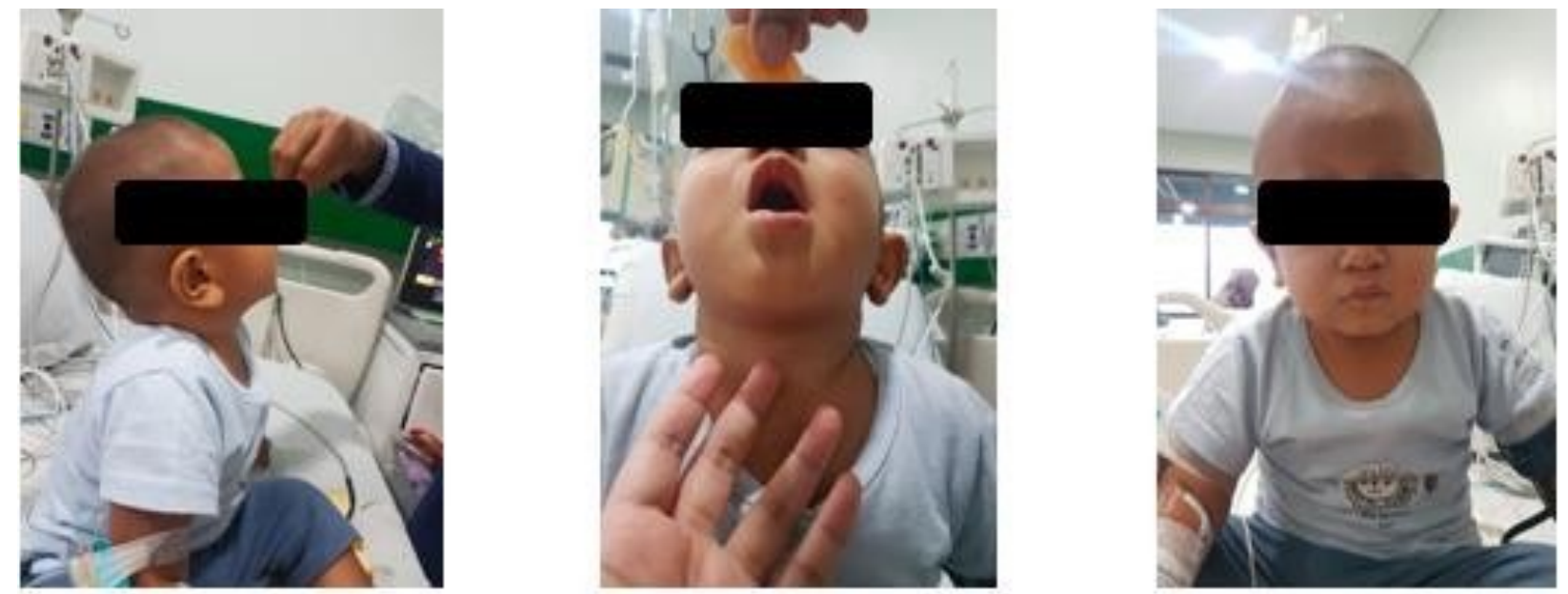

Gambar 6. Foto pasien 3 saat preoperatif

pasca pembiusan di PICU, kondisi pasien relatif stabil, dengan denyut nadi 90-100x/menit, tekanan darah 900-100/50-700 mmHg dan saturasi oksigen $98-100 \%$ dalam udara ruang. Pada hari berikutnya, pasien dapat dipindahkan ke ruang rawat biasa tanpa ada penyulit. Pasien pulang ke rumah pada perawatan hari kedua pascaoperasi.

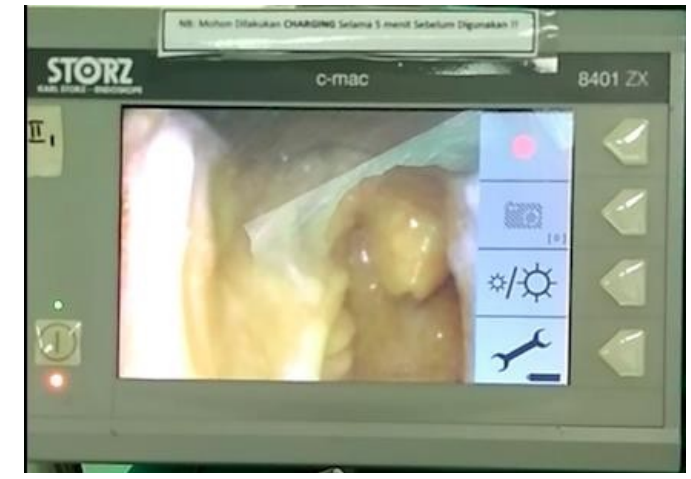

Gambar 7. Gambaran epiglotis letak tinggi

\section{PEMBAHASAN}

isakaridosis merupakan penyakit genetik herediter yang progresif akibat adanya mutasi pada gen yang mengkoding enzimenzim lisosom sehingga terjadi defisiensi dari enzim lisosom tertentu yang menyebabkan penumpukan sebagian dari glikosaminoglikan (GAGs). ${ }^{2}$ Prevalensi dari penyakit ini secara keseluruhan adalah 3.5-4.5 dari tiap 100.000 kelahiran. Mukopolisakaridosis (MPS) tipe II atau sindrom Hunter memiliki angka kejadian sekitar 1 dari 162.000 orang di dunia. ${ }^{3,4}$

MPS tipe II, yang dikenal dengan sindrom Hunter, merupakan kelainan terkait kromosom $\mathrm{X}$ yang disebabkan oleh defisiensi enzim iduronate 2-sulfatase (IDS). Gen yang mencetak IDS terdapat pada kromosom Xq28. Pada $80 \%$ penderita memiliki mutasi pada gen ini, sementara $20 \%$ sisanya terdapat delesi atau perubahan susunan dari gen IDS yang berkaitan dengan klinis yang lebih berat. Karena merupakan kelainan resesif yang diturunkan oleh kromosom $\mathrm{X}$, manifestasi klinis terutama terjadi pada pria.

Pasien dengan MPS tipe II memiliki gejala yang mirip dengan Hurler disease (MPS tipe I), seperti adanya hepatosplenomegali, bentuk muka yang kasar, lidah yang besar, dahi yang menonjol, kekakuan sendi, perawakan pendek, dan displasia tulang. Kebanyakan pasien MPS tipe II juga memiliki gejala infeksi telinga dan saluran napas yang berulang, napas yang berbunyi, dan memiliki penyakit obstruksi jalan napas. Keterlibatan neurologis yang progresif lambat dan dapat menyebabkan kematian yang umumnya terjadi pada usia 10-15 tahun. ${ }^{4}$

\section{Tatalaksana Jalan Napas}

Karena penyakit ini bersifat progresif, pasien MPS sering membutuhkan pembedahan maupun prosedur pemeriksaan diagnostik yang membutuhkan pembiusan. Spinello dkk menyatakan risiko anestesi pada MPS tipe II (Sindrom Hunter) tinggi karena adanya 
kemungkinan gangguan multisistem organ yang meliputi kecenderungan untuk obstruksi jalan napas atas, sulit intubasi, sekresi sekret yang tebal pada jalan napas atas, kemungkinan gangguan jantung, dan kemungkinan hipolasia odontoid. $^{2}$ Pada kasus pasien 1, 2 dan 3 risiko anestesi tinggi hampir sama yaitu terdapat abnormalitas jalan napas, kelainan ortopedi, dan keterlibatan jantung dan neurologi. Begitu pula kemungkinan gangguan multisistem pada ketiga pasien juga hampir sama.

Angka insiden sulit intubasi pada pasien MPS bervariasi, yakni berkisar antara $28-44 \%$ dengan angka kegagalan yang juga bervariasi antara 8-34\%. ${ }^{1,5}$ Jalan napas atas pada pasien-pasien MPS dapat menyempit akibat akumulasi GAGs yang menyebabkan makroglosia, hipertrofi adenoid dan tonsil serta penebalan jaringan lunak pada laringofaring.

Obstruksidapatdisebabkantrakeobronkomalasia atau akumulasi GAG pada mukosa trakea dan laring sehingga menyulitkan identifikasi glotis. Sekresi yang berlebihan pada jalan napas atas dan bawah juga dapat turut memperberat obstruksi. Derajat mengorok atau obstruksi jalan napas ketika tidur juga merupakan bagian yang penting dalam anamnesis. Pasien MPS dengan riwayat OSA memiliki risiko tinggi mengalami kegawatan pada anestesi. ${ }^{6}$

Pada kasus pasien 1 , pasien pernah 2 kali menjalani sedasi untuk pemeriksaan CT Scan dan MRI kurang lebih satu tahun sebelum operasi ini dan dikatakan relatif tanpa masalah. Adanya perkembangan terakhir suara mengorok pasien pada saat tidur yang relatif semakin keras, menunjukkan kemungkinan adanya perubahan anatomi pada jalan napas atas. Risiko kemungkinan kesulitan intubasi pada pasien ini terutama karena ukuran lidah pasien yang besar dan juga kekakuan pada leher pasien yang menyebabkan tidak dapat dilakukan ekstensi leher dan risiko intubasi yang tinggi. Pasien kedua yang pernah menjalani prosedur CT scan dengan sedasi tanpa masalah. Pasien yang kedua telah menjalani dua kali operasi tonsil, yang pertama dengan intubasi direk laringoskopi kemudian yang kedua intubasi dengan video laringoskopi. Pasien ketiga tidak dilakukan CT scan dan belum pernah ada riwayat pembiusan sebelumnya sehingga tidak ada datanya.
Sejak tahun 2009, penggunaan video laringoskopi telah banyak dilakukan untuk intubasi pada pasien MPS. Theroux dkk mengevaluasi secara restrospektif mengenai intubasi terhadap 28 pasien MPS yang menjalani 108 prosedur anestesi dan menyimpulkan video laringoskopi merupakan metode yang lebih disukai. Tinjauan oleh Megens dkk mengenai angka keberhasilan intubasi pada beberapa alat menunjukkan kesulitan menggunakan laringoskopi langsung (direct laryngoscopy) terjadi pada 16 dari 55 prosedur anestesi. Video laringoskopi berhasil pada 8 dari 9 prosedur, dan bronkoskopi fiberoptik hanya mudah dilakukan pada 2 dari 10 kasus. ${ }^{5}$ Mudahnya insersi LMA pasien pada literatur diterapkan pada pasien ini dengan difasilitasi penggunaan intubating LMA (iLMA) Fastrach. Suatu studi perbandingan menunjukkan penggunakan iLMA dibandingkan dengan fiberoptik pada pasien dengan kesulitan intubasi memiliki angka desaturasi serta efek samping perdarahan dan bronkospame yang lebih kecil dibandingkan fiberoptik. Namun keduanya tetap memiliki angka keberhasilan yang tinggi yaitu $92 \%$ dan $94 \%{ }^{7,8}$ American Society of Anesthesiologist pada tahun 2001 telah mempublikasikan suatu artikel yang menjelaskan suatu teknik intubasi fiberoptik melalui LMA standar. ${ }^{9}$ Lee dkk melaporkan penggunaan intubasi fiberoptik melalui LMA pada dua kasus pasien sulit intubasi dengan instabilitas servikal karena fusi pada seluruh servikal, dan salah satunya adalah pasien anak usia 6 tahun. Laporan kasus tersebut menunjukan intubasi dapat dilakukan dengan mudah tanpa periode desaturasi dan LMA dapat diinsersi tanpa menggerakkan tulang servikal. Dilaporkan juga bahwa intubasi hanya membutuhkan waktu 5 menit dari semenjak pelumpuh otot diberikan. ${ }^{10}$

Pada pasien kasus 1, intubasi dirasakan sulit dengan menggunakan CMAC, glidescope, fiberoptik, maupun kombinasi C-MAC dengan bougie, glidescope dan fiberoptik. Intubasi baru berhasil dilakukan setelah mengkombinasikan 3 alat sekaligus yaitu fiberoptik, LMA, dan bougie. Pemeriksaan fiberoptik dan bougie dapat dimasukkan secara bersamaan melalui LMA merupakan hal yang penting dilakukan sebelum teknik ini dilakukan. Pada kasus 2, intubasi 
dilakukan dengan video laringoskop dan bougie dan kasus 3 intubasi dilakukan dengan direk laringoskopi dan bougie dikarenakan blade video laringoskop yang sesuai untuk pasien tersebut rusak.

\section{KESIMPULAN}

Seluruh kelainan pada sindrom Hunter bersifat progresif sehingga akan memburuk seiring waktu dan menjadikan pembiusan lebih sulit. Walau anestesi lokal dengan blok perifer lebih dianjurkan, hal tersebut sulit dilakukan terutama pada pasien dengan retardasi mental dan tidak kooperatif. Anestesi umum dengan intubasi menjadi pilihan utama, namun penyulit jalan napas pada kelompok pasien dengan sindrom Hunter perlu diwaspadai. Maka dari itu, ahli anestesi sebaiknya melakukan prosedur multipel dalam satu tindakan anestesi, termasuk intubasi untuk mempertahankan jalan napas selama anestesi umum.

\section{DAFTAR PUSTAKA}

1. Hut RSCM, Menkes Resmikan Layanan Penyakit Langka dan Implantasi Koklea. Kementerian Kesehatan Republik Indonesia. 2017 Nov 4. Diunduh dari :http://www. depkes.go.id/article.ht $\mathrm{ml}$ pada tanggal 26 Juni 2020.

2. Spinello CM, Novello LM, Pitino S, Raiti C, Murabito P, Stimoli F, et al. Anesthetic Management in Mucopolysaccha ridoses. ISRN Anesthesiol. 2013;2013:1-10.

3. Hafifah CN. Apakah Itu Penyakit Langka [Internet]. Yayasan MPS dan Penyakit langka Indonesia. Diunduh dari: https:// penyakitlangkaindonesia.org pada tanggal 26 Juni 2020.
4. Lampe, Dr. Christina. 2018. Pathophysiology of Mucopolysaccharidosis. The Center for Rare Diseases, Clinics for Pediatric and Adolescent Medicine Helios Dr. Horst Schmidt Kliniken, Wiesbaden, Germany

5. Clark BM, Sprung J, Weingarten TN, Warner ME. Anesthesia for patients with mucopolysacchari doses: Comprehensive review of the literature with emphasis on airway management. Bosn J Basic Med Sci [Internet]. 26 Juni 2020. Diunduh dari: https:// www.bjbms.org/ojs/index.php/bjb ms/article/view/2201 pada tanggal 26 Juni 2020

6. Walker R, Belani KG, Braunlin EA, Bruce IA, Hack $H$, Harmatz PR, et al. Anaesthesia and airway management in mucopolysaccha ridosis. J Inherit Metab Dis. 2013 Mar;36(2):211-9.

7. Langeron $\mathrm{O}$, Semjen $\mathrm{F}$, Bourgain JL, Marsac A, Cros AM. Comparison of the intubating laryngeal mask airway with the fiberoptic intubation in anticipated difficult airway management. Anesthesiology. 2001 Jun;94(6):968-72.

8. and Indirect Intubating Aids in Airway Management. In: Khan ZH, editor. Airway Management. Springer International Publishing; 2014. p. 33-70.

9. Thong S-Y, Teoh WHL. Videolaryngoscopy A New Technique of Fiberoptic Intubation through a Standard LMA TM. Anesthesiology. 2001 Dec 1;95(6):1541-1541

10. Lee JJ, Lim BG, Lee MK, Kong MH, Kim KJ, Lee JY. Fiberoptic intubation through a laryngeal mask airway as a management of difficult airwary due to the fusion of the entire cervical spine - A report of two cases -. Korean J Anesthesiol. 2012;62(3):272. 